ІННОВАЦІЙНА ОРГАНІЗАЦІЯ МЕТОДИЧНОЇ РОБОТИ В НОВІЙ УКРАЇНСЬКІЙ ШКОЛІ

\title{
INNOVATIVE ORGANIZATION OF METHODICAL WORK IN THE NEW UKRAINIAN SCHOOL
}

У статті розкрита інноваційна організація методичної роботи. Зазначено, що традиційна система організації методичноі роботи в загальноосвітніх закладах середньої освіти не задовольняє повною мірою запит сучасної нової освіти, спрямованість якої зумовлена підготовкою вчителя до педагогічної діяльності в контексті Нової української школи. Контекст державної політики та стратегії розвитку освіти в Україні орієнтує на нове осмислення методичноі роботи як важливого чинника реалізації концепції «Нова українська школа». Посилюється тенденція затребуваності суспільством інновацій в освіті, що зумовлює необхідність розробки принципово нових підходів до взаємодії педагогічної науки та практики, запровадження сучасних технологій методичного менеджменту. Зазначено, що впровадження інноваційної організації методичної роботи полягає саме в розвитку педагогіч ної культури вчителя. Запропонована В.К. Буряком концепція визначається фрормулою «МИ» як показник суб'єкт-суб'єктноі педагогічної діяльності. Визначена концепція $\epsilon$ логічним продовженням педагогіки співробітництва і в той же час виступає як нова спіраль у діалектичному розвитку інноваційної педагогіки. Разом із тим в наш час простежується недооцінка підготовки керівників до управління прочесом організації підвищення рівня профессійної підготовки вчителів З3СО. Важливо усвідомити, що процес підвищення профресійної кваліфрікації педагогів повинен будуватися на основі цілісного підходу, що дозволяє розглядати всі дидактичні засоби як засіб професійного становлення педагогічної культури. Сучасна система організації методичної роботи такої можливості не дає, оскільки управління цим процесом здійснюється примусово-виконавчим $і$ адміністративно-командним сти лем, у процесі якого вирішуються специорічні завдання без урахування творчого потенціалу педагогічного колективу. Згідно з цим принципом кінцевий результат методичноі освіти вчителів виокремлює із загальної структури їх профресійності лише інсрормативний аспект, а розвивальний потенціал підвищення квалісрікації педагогів не враховується. Проте сьогодні педагогічна наука ще не знайшла аргументованої відповіді на ряд питань щодо підготовки керівників до організації методичної роботи, зокрема на питання щодо виявлення сутності готовності керівників до підвищення професійності вчителів 3ЗСО.

Ключові слова: методична робота, інноваційна методична робота, традиційна методична робота, інновації, педагогічна культура.

An innovative organization of methodical work is revealed in the article. It is noted that the traditional system of organizing methodological work in the HSE does not fully satisfy the request of modern new education, the orientation of which is conditioned by the teacher's preparation for pedagogical activity in the context of the New Ukrainian School. The context of public policy and strategy for the development of education in Ukraine is orienting itself to a new understanding of methodical work as an important factor in the implementation of the New Ukrainian School concept. The tendency of demand for innovations in education by the society is increasing, which necessitates the development of fundamentally new approaches to the interaction of pedagogical science and practice, the introduction of modern technologies of methodological management.

It is stated that the introduction of innovative organization of methodological work is precisely in the development of teacher's pedagogical culture. The concept proposed by VK Buryak is defined by the formula "WE" as an indicator of subject-subject pedagogical activity. The defined concept is a logical continuation of the pedagogy of cooperation and at the same time acts as a new spiral in the dialectical development of innovative pedagogy. Taking this theory as a guideline, it is complemented by such features of the concept of pedagogical culture - a personal formation of the teacher, characterized by humanistic relations with all participants in methodical work in order to create a competitive team, which is dominated by a positive social and psychological climate, effective and efficient. Teachers, as a result, have professional knowledge, teaching techniques, use a computer and are ready to help each student reach their full potential. Key words: methodological work, innovative methodological work, traditional methodical work, innovations, pedagogical culture.

неперервної освіти

Дніпропетровської обласної ради»

Постановка проблеми в загальному вигляді. У системі освіти стрімко відбуваються зміни, сутність і стратегічний напрям яких визначає концепція «Нова українська школа». У зв'язку зі змінами перед педагогами виникають нові завдання, одним із яких $€$ вдосконалення процесу підвищення рівня профресійної підготовки вчителів закладів загальної середньої освіти (далі - 33СО). Вирішення цих проблем актуалізує значимість методичної роботи у З3СО, завданням якої є підвищення профресійної квалісікації вчителів.
Аналіз останніх досліджень і публікацій. Багато науковців розглядають проблему організації методичної роботи в школі (Ю.К. Бабанський, Н.П. Волкова, В.І. Кудзоєва, Т.С. Рабченюк та інші). Причому має місце досить неординарний підхід щодо визначення самої суті цього поняття. Різні автори розглядають це поняття в різних ракурсах:

- як форму організації підвищення професійності компетентності вчителів (Ю.К. Бабанський, Н.П. Волкова, В.І. Кудзоєва, Т.С. Рабченюк та інші); 
- як умову розвитку педагогічної творчості (Т.О. Берсенєва, Л.Б. Білієнко, Н.В. Дудниченко, В.В. Загвязинський, С.П. Максимюк, Є.Г. Повар);

- як допомогу у фрормуванні наукової організації навчального процесу (Г. Азаріашвілі, В.М. Головінов і В.Л. Головінова, І.П. Жерносек, В.Д. Зотова, О.Є. Остапчук);

- як засвоєння досягнень науки і передового досвіду (Г.Є. Гребенюк, О.Д. Деменцев, І.П. Жерносек, Ф.В. Касабаєва, К.П. Кіндрат, Ф.О. Красовський, Р.Ф. Кулдавлєтов, В.Т. Лозовецька, М.Д. Нікандров, Є.Д. Петрова та інші);

- інші - як організацію підвищення кваліфікації та атестації педагогічних працівників (Т.Р. Абдулаєв, О.О. Автомонова, В.І. Бондар, Х.І. Золотар, С.П. Мануйленко, О.М. Овдієнко).

- Т.М. Сорочан, зазначає, що в системі освіти стрімко відбуваються зміни, сутність і стратегічний напрям яких визначає концепція «Нова українська школа».

Методисти, методичні установи та методичні об'єднання мають визначити власну місію в цьому процесі, спрямувати діяльність на забезпечення есрективності рефрорм. Контекст державної політики та стратегії розвитку освіти в Україні орієнтує на нове осмислення методичної роботи як важливого чинника реалізації концепції «Нова українська школа». Посилюється тенденція затребуваності суспільством інновацій в освіті, яка в свою чергу зумовлює необхідність розробки принципово нових підходів до взаємодії педагогічної науки та практики, запровадження сучасних технологій методичного менеджменту.

Виділення не вирішених раніше частин загальної проблеми. Із проаналізованого матеріалу можемо зробити висновок, що традиційна система організації методичної роботи в 33СО не задовольняє повною мірою запит сучасної нової освіти, спрямованість якої зумовлена підготовкою вчителя до педагогічної діяльності в контексті Нової української школи. Як показав аналіз педагогічної практики, традиційна організація методичної роботи зводиться лише до викладання уроків, написання методичних розробок, посібників, як наслідок зреалізованою є тільки фрункція повідомлення, констатування теоретичних положень, методичних пропозицій. Проте стійкі стереотипи традиційної організації методичної роботи залишають поза увагою найголовнішу фуункцію методичної роботи - створення творчого педагогічного колективу однодумців, який спроможний вирішувати складні педагогічні задачі, координувати активність педагогів для взаєморозуміння у процесі формуванні єдиних вимог, критеріїв і стандартів педагогічної культури .

Мета статті. Розглянути найбільш доцільний спосіб організації методичної роботи, яка б в повній мірі відповідала педагогічним вимогам Нової української школи.
Виклад основного матеріалу. Традиційна організація методичної роботи визначається нами як комплекс адміністративно-командних розпоряджень керівників методичної роботи, спрямованих на розробку методичного забезпечення навчального процесу . Із цього визначення можна зробити висновки, що організація здійснюється за принципом суб'єкт-об'єктної взаємодії керівників із вчителями, де керівники виступають суб'єктами (вони є активними), а педагоги виступають об'єктами управління як виконавці (вони є пасивними).

Ефрективність методичної роботи, згідно 3 нашою гіпотезою, може бути досягнена за умов перебудови традиційного підходу керування методичною роботою на інноваційну, що зумовить фрормування педагогічної культури учителів. Вчений В.К. Буряк зазначає такі основні ознаки педагогічної культури : «<...>педагогічна культура являє собою інтегративну характеристику педагогічного процесу, що включає єдність як безпосередньої діяльності людей з передачі накопиченого соціального досвіду, так і результати цієї діяльності, закріплені у вигляді знань, умінь, навичок і спеціальних інститутів такої передачі від одного покоління до іншого» [1].

Теоретичним обґрунтуванням змісту педагогічної культури в нашому дослідженні послужила думка вченого про те, що «педагогічна культура $€$ культура виховання й освіти». Отже, рівень педагогічної культури людини визначається тим, якою мірою ця людина виконує роль вихователя й педагога. Останнє залежить від ряду фракторів, серед яких можна виділити: 1) обсяг знань, якими володіє людина; 2) його життєвий досвід, людську мудрість; 3) навички й уміння передачі власних знань [1].

Ми вважаємо, що впровадження інноваційної організації методичної роботи полягає саме в розвитку педагогічної культури вчителя. Запропонована В.К. Буряком концепція визначається фрормулою «МИ» як показник суб'єкт-суб'єктної педагогічної діяльності. Визначена концепція $€$ логічним продовженням педагогіки співробітництва і в той же час виступає новою спіраллю в діалектичному розвитку інноваційної педагогіки. Узявши цю теорію за орієнтир, ми доповнюємо їі такими ознаками: поняття педагогічної культури це особистісне утворення педагога, що характеризується гуманістичними стосунками 3 усіма учасниками методичної роботи з метою створення конкурентноспроможного колективу, в якому панує позитивний соціально-психологічний клімат, що зумовлює еоективну працездатність. Як наслідок, учителі володіють професійними знаннями, методикою викладання фрахової дисципліни, використовують комп'ютер і готові допомогти кожному учню розкрити свій потенціал. Ми спираємося, що очевидно, на положення про розвиток творчого 
мислення педагога, здібності адаптуватися до навчально-виховного процесу у складних психолого-педагогічних ситуаціях, що дозволяє йому, педагогу, повноцінно сприймати динамічні зміни фахової, психологічної та педагогічної наук, реалізувати себе відповідно до позиції гуманістичного підходу у взаємодії з учасниками навчального процесу.

Суттєві ознаки, що розкривають суть поняття «інноваційна організація методичної роботи», складаються 3:

1) мети організації методичної роботи;

2) утілення інноваційної стратегії організації процесу навчання вчителів методичній роботі;

3) сукупності педагогічних технологій із реалізації нової фрілософрії освітньої діяльності, нового типу відносин між педагогами й учнями, нової «технології» опанування знань, нової організації навчального процесу, що характеризує «прозорість»;

4) правил, що регулюють відносини між усіма учасниками навчального процесу з метою стимулювання активності вчителів до участі в методичній роботі.

Наведемо порівняльну характеристику змісту традиційної організації методичної роботи з інноваційною (див. табл. 1).

На нашу думку, ефрективність розвитку педагогічної культури вчителів залежить, з одного боку, від сорормованої готовності керівників до інноваційної організації діяльності, а з іншого - від сфрор- мованої готовності вчителів активно брати участь у ній.

Разом із тим в наш час простежується недооцінка підготовки керівників до управління процесом організації підвищення рівня профресійної підготовки вчителів 33СО. Важливо усвідомити, що процес підвищення профресійної кваліфрікації педагогів повинен будуватися на основі цілісного підходу, що дозволяє розглядати всі дидактичні засоби як засіб професійного становлення педагогічної культури. На нашу думку, сучасна система організації методичної роботи такої можливості не дає, оскільки управління цим процесом здійснюється у примусово-виконавчому й адміністративнокомандному стилі, у процесі якого вирішуються специфічні завдання без урахування творчого потенціалу педагогічного колективу. Згідно з цим принципом кінцевий результат методичної освіти вчителів виокремлює із загальної структури їх професійності лише інформативний аспект, а розвивальний потенціал підвищення кваліфікації педагогів не враховується. Проте сьогодні педагогічна наука ще не знайшла аргументованої відповіді на ряд питань щодо підготовки керівників до організації методичної роботи, зокрема на питання щодо виявлення сутності готовності керівників до підвищення профресійності вчителів 33СО.

Готовність до організації методичної роботи розглядається нами як складне особистісне утворення, що містить знання і вміння оперувати плануванням, керуванням, контролем і корекцією

\section{Порівняння значущих факторів організації методичної роботи} у традиційній та інноваційній стратегії

\begin{tabular}{|l|l|l|}
\hline \multicolumn{1}{|c|}{$\begin{array}{l}\text { Параметри організації } \\
\text { методичної роботи }\end{array}$} & \multicolumn{1}{|c|}{$\begin{array}{c}\text { Традиційна організація } \\
\text { методичної роботи }\end{array}$} & \multicolumn{1}{|c|}{$\begin{array}{c}\text { Інноваційна організація } \\
\text { методичної роботи }\end{array}$} \\
\hline $\begin{array}{l}\text { Організація навчання } \\
\text { у методичній роботі } \\
\text { (Дієвий показник) }\end{array}$ & $\begin{array}{l}\text { Автономна взаємодія в організації } \\
\text { методичної роботи. Керівник знає, } \\
\text { що треба зробити, планує і } \\
\text { розподіляє завдання методичної } \\
\text { роботи. Вчителі не обговорюють } \\
\text { завдання, а сприймають їх як } \\
\text { обов'язкові для виконання }\end{array}$ & $\begin{array}{l}\text { Корпоративна взаємодія } \\
\text { ворганізації методичної роботи. } \\
\text { Керівник і вчителі обговорюють } \\
\text { програму методичної роботи, } \\
\text { корегують, уточнюють і розподіляють } \\
\text { її виконання за календарним } \\
\text { та особистісним планом }\end{array}$ \\
\hline $\begin{array}{l}\text { Стилі спілкування } \\
\text { (особистісний показник) }\end{array}$ & $\begin{array}{l}\text { Командно-адміністративний, } \\
\text { управлінський, авторитарний } \\
\text { (прихований, відкритий); егоїстичний } \\
\text { підхід у виборі пріоритетів }\end{array}$ & $\begin{array}{l}\text { Демократичний, особистісно } \\
\text { зорієнтований підхід у взаємодії; } \\
\text { гуманне ставлення до особистості, } \\
\text { колективний вибір пріоритетів }\end{array}$ \\
\hline $\begin{array}{l}\text { зміст діяльності організації } \\
\text { методичної роботи } \\
\text { (мотиваційний, особистісний, } \\
\text { когнітивний, операційний } \\
\text { показники) }\end{array}$ & $\begin{array}{l}\text { Змістова сторона діяльності } \\
\text { методичної роботи спрямована } \\
\text { на виконання планів, наказів, } \\
\text { рекомендацій тощо. } \\
\text { Результати методичної роботи } \\
\text { представлені у репродукуванні } \\
\text { вже набутих науково-методичних } \\
\text { досягнень }\end{array}$ & $\begin{array}{l}\text { 3містова сторона діяльності у } \\
\text { методичній роботі спрямована } \\
\text { на саморозвиток особистості, } \\
\text { творчу реалізацію її професійних } \\
\text { здібностей. Результати методичної } \\
\text { роботи представлені в новаторських } \\
\text { розробках навчання учнів }\end{array}$ \\
\hline $\begin{array}{l}\text { Контроль і оцінка організації } \\
\text { методичної роботи }\end{array}$ & $\begin{array}{l}\text { Суб'єктивна оцінка результативності } \\
\text { методичної роботи подана керівником }\end{array}$ & $\begin{array}{l}\text { Об'єктивна оцінка результативності } \\
\text { методичної роботи подана } \\
\text { самооцінкою вчителя, оцінкою } \\
\text { педагогічного колективу й керівника }\end{array}$ \\
\hline
\end{tabular}


змісту освітньої програми методичної роботи та вміння вирішувати завдання, які виникають у процесі підвищення професійного рівня вчителів 33CO.

Критерій готовності до інноваційної організації методичної роботи представлений нами такими структурними компонентами:

- мотиваційний показник: позитивна мотивація і спрямованість керівників на інноваційну організацію методичної роботи, позитивна мотивація вчителів брати участь у методичній роботі;

- змістовний показник знань, умінь і навичок (когнітивний $і$ дієвий): знання керівників про технологію наукового управління педагогічним колективом; знання учасників методичної роботи про інноваційну технологію навчання та її роль у професійній діяльності педагога (ступінь усвідомленості, практичної значущості, компетентність, глибина і всебічність знань) уміння керівників ефективно керувати організацією методичної роботи, уміння створювати позитивний соціальнопсихологічний клімат, уміння впроваджувати педагогічну технологію з розвитку особистості; уміння втілювати інноваційні технології, уміння використовувати комп'ютерну техніку;

- особистісний показник: спрямованість змісту методичної роботи на всебічний розвиток творчої особистості вчителя; на фрормування комунікативних умінь і гуманістичної спрямованості.

Визначені критерії дали можливість описати такі рівні організації методичної роботи.

1. Примусово-виконавчий (низький рівень) характеризується відсутністю наукової організації управління, стихійним виконанням завдань, егоїстичною спрямованістю у визначенні пріоритетів при виконанні завдань з методичної роботи, непослідовністю суворого дотримання мети і здійснення контролю за своїми діями, провокує дискомфорт та негативний соціально-психологічний клімат, використовує традиційний підхід у навчанні дітей.

2. Репродуктивно-виконавчий (нижчий за середній) відзначається адміністративно-командним стилем управління методичною роботою, репродуктивним виконанням завдань, егоцентричною спрямованістю у визначені пріоритетних цілей і завдань методичної роботи, відсутністю особистісної позиції та провокуванням суперечності у взаємодії з учасниками методичної роботи, користуванням традиційною організацією навчання.

3. Ініціативно-особистісний (середній рівень) визначає адміністративно-командний стиль управління методичною роботою, творче ставлення до виконання завдань із методичної роботи, нама- гання створити нове, оригінальне для навчальновиховного процесу , егоцентричну спрямованість у визначені пріоритетних цінностей, намагання підтримувати позитивний соціально-психологічний клімат, зацікавленість до впровадження передового педагогічного досвіду, хоча й без наукового обґрунтування.

4. Інноваційно-творчий (високий рівень) характеризується науково-методичним підходом до управління методичною роботою і намаганням створити конкурентоздатну команду педагогів, творчим виконанням завдань у методичній роботі; створенням позитивного соціально-психологічного клімату, впровадженням інноваційних технологій.

Висновки. Отже, суть інноваційної організації методичної роботи принципово відрізняється від традиційної організації, оскільки:

1) на перший план виступає змістовний матеріал методичних занять, у яких розкривається сутність нової фрілософрії освітньої діяльності, нові принципи організації навчального процесу, новий тип відношень між вчителем і учнем, нові «технології» опанування знань, це унеможливлює репродуктивні методи навчання, це прозорість навчального процесу;

2) на другий план організації методичної роботи виступають завдання щодо вироблення потреби у вчителя фрормувати педагогічну культури в організації навчально-виховного процесу методичної роботи;

3) на третій план організації методичної роботи виноситься питання формування свідомого розуміння значимості особистісно-орієнтованої позиції в навчальному процесі, в якому переважає організаційна і стимулююча фрункція (кожний учасник навчального процесу виступає як цілісна особистість, що взаємодіє з іншими);

4) на четвертий план організації методичної роботи ми відносимо фрункціональні педагогічні завдання, що стимулюють активність учителів у розвитку педагогічної культури.

\section{БІБЛІОГРАФІЧНИЙ СПИСОК:}

1. Буряк В.К. Педагогічна культура: теоретикометодологічний аспект. Київ: «Деміург», 2005. 232 с.

2. Гапоненко Л.О. Теорія і практика підготовки студентів до педагогічного спілкування: монографрія. Дніпропетровськ: Пороги, 1997. 226 с.

3. Набока Л.М. Діяльність методиста щодо розповсюдження педагогічних інновацій. Управління освітою. 2002, № 12. С. 7-12.

4. Сорочан Т.М. Методична робота: підготовка вчителів до реалізації концепції «Нова українська школа». Методист. 2018. 